\title{
Assessment of knowledge, attitude and practices on antibiotic resistance among undergraduate medical students in the school of medicine at the University of Zambia
}

\author{
Annie Zulu' ${ }^{1}$, Scott K. Matafwali ${ }^{2}$, Michelo Banda' ${ }^{1}$, Steward Mudenda1*
}

\author{
${ }^{1}$ Department of Pharmacy, School of Health Sciences, University of Zambia, Lusaka, Zambia \\ ${ }^{2}$ Department of Basic Sciences, School of Medicine, Copperbelt University, Ndola, Zambia
}

Received: 19 December 2019

Revised: 14 January 2020

Accepted: 16 January 2020

*Correspondence:

Mr. Steward Mudenda,

Email: steward.mudenda@unza.com

Copyright: (C) the author(s), publisher and licensee Medip Academy. This is an open-access article distributed under the terms of the Creative Commons Attribution Non-Commercial License, which permits unrestricted non-commercial use, distribution, and reproduction in any medium, provided the original work is properly cited.

\begin{abstract}
Background: The issue of antibiotic resistance has become a global public health concern, with an extensive clinical and economic burden. The study aimed to assess the knowledge, attitude, and practices of antibiotic resistance among undergraduate medical students at the University of Zambia.

Methods: This cross-sectional study was conducted at the University of Zambia Ridgeway Campus. A structured questionnaire was administered to 260 randomly selected undergraduate medical students. Data were analyzed using Statistical Package for Social Sciences (SPSS) version 22.0. Associations between dependent and independent variables were done using a Chi-square test. The statistical significance was done at $95 \%$ confidence level $(\mathrm{p}<0.05)$. Ethical approval was done by the University of Zambia Health Sciences Research Ethics Committee.

Results: The study found that 227 of $260(87.3 \%)$ of the medical students had good knowledge on antibiotic use and resistance. The majority of the medical students 252 of $260(96.9 \%)$ had positive attitudes and 195 of 260 (75\%) had good practices towards antibiotic resistance. There was a significant difference between the year of study and the level of knowledge $\left(\chi^{2}=16.333, p=0.003\right)$. There was no significant difference between the year of study and the attitude of the participants $\left(\chi^{2}=4.061, \mathrm{p}=0.398\right)$. A significant difference was found between the year of study and the practices of the respondents $\left(\chi^{2}=10.926, \mathrm{p}=0.027\right)$.

Conclusions: The medical students had good knowledge, a positive attitude, and good practices towards antibiotic resistance. Final year students had higher levels of knowledge and attitude but lower levels of practice compared to other years of study.
\end{abstract}

Keywords: Antibiotic resistance, Attitude, Knowledge, Medical students, Practices, Zambia

\section{INTRODUCTION}

The problem of antibiotic resistance is a global public health concern that causes increased morbidity, mortality, and economic burden. ${ }^{1,2}$ Medical students should not only be made aware of the current emerging health issues but also be directed towards rational antibiotics prescribing behavior as future medical practitioners. ${ }^{3}$ It has been recommended that adequate training on antimicrobial prescribing and resistance should be provided to the undergraduate medical students to reduce antibiotic resistance $(\mathrm{ABR}){ }^{4}$

Antimicrobial resistance (AMR) occurs when infectious agents' adaptation to exposure to antimicrobials used in human and veterinary medicine. ${ }^{5}$ Some factors leading to 
AMR include self-medication, absence of diagnostic tools, dispensing of antibiotics without prescriptions, inappropriate prescribing of antimicrobials by doctors. ${ }^{6}$ Many factors could influence doctors' decisions, leading them to breach the principles of good clinical practice. ${ }^{7}$ Factors such as patients' demands, doctors' personal experiences and preferences, lack of culture and sensitivity results leading to uncertain diagnosis, sale of antibiotics without prescription are some of the most common contributors towards antibiotic resistance, poor knowledge and lack of knowledge on rational prescribing and AMR. ${ }^{8,9}$

Knowledge and beliefs influence health-related behavior with regards to using antibiotics. ${ }^{10}$ Inappropriate attitudes and lack of knowledge towards the use of antibiotics is a high-risk factor contributing to the rise of AMR cases. ${ }^{11}$

AMR has bought about challenges to the effective prevention and treatment of infections caused by bacteria, fungi, parasites, and viruses. ${ }^{1}$ Some of the multi-drug resistance (MDR) microorganisms that are a global public health challenge include Pseudomonas aeruginosa, Staphylococcus aureus and Escherichia coli bearing extended-spectrum $\beta$-Lactamases (ESBL). ${ }^{12}$ These strains of microorganisms are resistant to the common antibiotic classes such as penicillins, cephalosporins, tetracyclines and polymyxins. ${ }^{13}$ Bacterial resistance to antimicrobial agents is classified as intrinsic resistance and acquired resistance. ${ }^{14}$ The intrinsic resistance of a species of bacteria to an antibiotic is the ability to resist the bactericidal or bacteriostatic effects of antibiotics. $^{15}$ Acquired resistance is attributed to the reduced cell permeability, production of drug-inactivating enzymes, and acquisition of a target by-pass system drug removal from the cell, and modification of an existing target. ${ }^{16}$

Antimicrobial Stewardship Program (ASP) is one major strategy used in the prevention and reduction of AMR. ${ }^{1,17,18}$ The cardinal aims of ASP include prevention or slowing the emergence of AMR, optimize antibiotic selection, promote rational prescribing, reduce hospital stay, emphasize the completion of antibiotic therapy, reduce adverse drug events, reduce morbidity and mortality. ${ }^{1,19}$

Future prescribers such as medical students need to have adequate information on antimicrobial resistance to tackle AMR adequately. ${ }^{20,21}$ However, to the best of our knowledge, there are no published studies that have been done in Zambia to assess these aspects.

\section{METHODS}

\section{Study setting and design}

This was a cross-sectional study design that was conducted from October 2018 to June 2019 at the
University of Zambia, Ridgeway campus in the School of Medicine in Lusaka, Zambia.

\section{Target population}

The study population consisted of 742 medical students from $3^{\text {rd }}$ to $7^{\text {th }}$ year. Participants were selected for the study using a simple random sampling method.

\section{Sample size determination}

Among total no. of population of 742 , third years was 175; fourth years was 152; fifth years was 140; sixth years was 149; seventh years was 126 .

Sample size of the study was 260 medical students.

\section{Distribution of sample size}

(Sample size $\div$ total population) $\times$ number of students in each class

$$
\begin{aligned}
& \text { 3rd year students }(260 \div 742) \times 175=61 \\
& 4 \text { th year students }(260 \div 742) \times 152=53 \\
& \text { 5th year students }(260 \div 742) \times 140=49 \\
& 6 \text { th year students }(260 \div 742) \times 149=52 \\
& 7 \text { th year students }(260 \div 742) \times 126=45
\end{aligned}
$$

\section{Data collection tool}

The data collection tool was developed according to a previous questionnaire used in China. ${ }^{22}$ The questionnaire was adapted to the setting of Lusaka and piloted among 15 undergraduate medical and 15 Bachelor of Pharmacy students. The dependent variables included knowledge, attitude, and practices whereas the independent variables include age, year of study, gender and religion.

\section{Data collection, analysis and presentation}

Data was collected from every questionnaire that was returned from participants. This was double-checked for accuracy and the data was sorted out manually. Microsoft Excel 2013 was used to enter and code data. Analysis of data was done using Statistical Package for Social Science (SPSS) version 22.0. A Chi-square test was used to test the relationship between the dependent and independent variables. The Statistical significance was set at $95 \%$ confidence level $(\mathrm{p}<0.05)$.

\section{Determining the knowledge of participants towards antibiotic resistance}

The participants who scored $>57 \%$ were classified as having good knowledge while those who scored $\leq 57 \%$ were considered as having poor knowledge of antibiotic resistance. 
Determining participants attitudes towards antibiotic resistance

Participants who scored $>51 \%$ were classified as having a positive attitude and those that scored $\leq 51 \%$ were classified as having a negative attitude towards antibiotic resistance.

\section{Determining participants practices towards antibiotic resistance}

Participants who scored $>51 \%$ were classified as having good practices and those that scored $\leq 51 \%$ were classified as having poor practices towards antibiotic resistance.

\section{Ethical consideration}

This study was conducted after ethical approval by the University of Zambia School of Health Sciences Research Ethics Committee (UNZAHSREC). Permission to conduct the study at the University of Zambia (UNZA) was obtained from the School of Medicine management.

\section{RESULTS}

\section{Socio-demographic characteristics of participants}

The study had a total of 260 undergraduate medical students of which the majority were male 177 of 260 (768.1\%). The majority of the participants were from the age group of 20-25 years 194 of $260(74.6 \%)$.

Table 1: Baseline characteristics of participants $(n=260)$.

\begin{tabular}{|c|c|c|c|}
\hline Variable & Characteristics & Frequencies & $\%$ \\
\hline \multirow{2}{*}{ Sex } & Female & 83 & 31.9 \\
\hline & Male & 177 & 68.1 \\
\hline \multirow{3}{*}{$\begin{array}{l}\text { Age (in } \\
\text { years) }\end{array}$} & $20-25$ & 194 & 74.6 \\
\hline & $26-30$ & 61 & 23.5 \\
\hline & $31-38$ & 5 & 1.9 \\
\hline \multirow{5}{*}{$\begin{array}{l}\text { Year of } \\
\text { study }\end{array}$} & 3rd year & 61 & 23.5 \\
\hline & 4th year & 53 & 20.4 \\
\hline & 5 th year & 49 & 18.8 \\
\hline & 6th year & 52 & 20.0 \\
\hline & 7 th year & 45 & 17.3 \\
\hline \multirow{3}{*}{ Religion } & Christian & 254 & 97.7 \\
\hline & Islam & 2 & 0.8 \\
\hline & Others & 4 & 1.5 \\
\hline
\end{tabular}

Table 2 shows that 258 out of 260 (99.2\%) responded correctly that antibiotics can cure bacterial infections while 243 out of $260(93.5 \%)$ responded that antibiotics can cure viral infections.

Table 3 shows that the majority of the participants 227 of $260(87.3 \%)$ had good knowledge and while 33 of 260 $(12.7 \%)$ had poor knowledge.
Table 2: Knowledge of participants on antibiotic use and resistance.

\begin{tabular}{|lll|}
\hline Knowledge questions & $\begin{array}{l}\text { Correct } \\
\text { response }\end{array}$ & $\begin{array}{l}\text { Wrong } \\
\text { response } \\
\text { N }(\%)\end{array}$ \\
\hline $\begin{array}{l}\text { Antibiotics can cure } \\
\text { bacterial infections }\end{array}$ & $258(99.2)$ & $2(0.8)$ \\
\hline $\begin{array}{l}\text { Antibiotics cannot cure } \\
\text { viral infections }\end{array}$ & $243(93.5)$ & $17(6.5)$ \\
\hline $\begin{array}{l}\text { Use of antibiotics will speed } \\
\text { up recovery of a cold }\end{array}$ & $130(50)$ & $130(50)$ \\
\hline $\begin{array}{l}\text { I have heard of antibiotic } \\
\text { resistance }\end{array}$ & $253(97.3)$ & $7(2.7)$ \\
\hline $\begin{array}{l}\text { Frequent use of antibiotics } \\
\text { can lead to ABR and } \\
\text { reduce the effectiveness of } \\
\text { treatment }\end{array}$ & $242(93.1)$ & $18(6.9)$ \\
\hline
\end{tabular}

Table 3: Participants knowledge response.

\begin{tabular}{|lll|}
$\begin{array}{l}\text { Knowledge of antibiotic } \\
\text { resistance }\end{array}$ & $\begin{array}{l}\text { Frequency } \\
(\mathbf{N})\end{array}$ & $\begin{array}{l}\text { Percentage } \\
(\%)\end{array}$ \\
\hline Good knowledge & 227 & 87.3 \\
\hline Poor knowledge & 33 & 12.7 \\
\hline Total & 260 & 100 \\
\hline
\end{tabular}

Table 4: Attitude of participants regarding antibiotic use and resistance $(n=260)$.

\section{Participants Attitude Frequency Percentage}

Abuse of AB has become the main cause of leading bacterial resistance?

\begin{tabular}{lll} 
Disagree & 19 & 7.3 \\
\hline Neutral & 15 & 5.8 \\
\hline Agree & 155 & 59.6 \\
Strongly agree & 71 & 27.3 \\
\hline
\end{tabular}

Is it necessary to get more education about antibiotics?

\begin{tabular}{lll} 
Disagree & 10 & 3.8 \\
\hline Neutral & 1 & 0.4 \\
\hline Agree & 125 & 48.1 \\
\hline Strongly agree & 124 & 47.7
\end{tabular}

Is there a need to establish a course on the "rational use of antibiotics?

\begin{tabular}{lll} 
Disagree & 29 & 11.2 \\
\hline Strongly disagree & 10 & 3.8 \\
\hline Neutral & 21 & 8.1 \\
\hline Agree & 126 & 48.4 \\
\hline Strongly agree & 74 & 28.5
\end{tabular}

Do you find it necessary to carry out large scale antibiotics campaign promotion?

\begin{tabular}{|lll|}
\hline Disagree & 21 & 8.1 \\
\hline Strongly disagree & 2 & 0.8 \\
\hline Neutral & 23 & 8.8 \\
\hline Agree & 138 & 53.1 \\
\hline Strongly agree & 76 & 29.2 \\
\hline
\end{tabular}


Table 4 shows that the majority of the participants 155 of $260(59.6 \%)$ agreed that the abuse of antibiotics has become the main cause leading to antibiotic resistance. The participants also agreed that it is necessary to get more education about antibiotics and there is a need to establish a course on the rational use of antibiotics.

Table 5 below shows that the majority of the participants 252 of $260(96.9 \%)$ exhibited a positive attitude and while the minority 8 of $260(3.1 \%)$ had a negative attitude towards antibiotic resistance.

Table 5: Participants attitude response.

\begin{tabular}{|lll|}
\hline $\begin{array}{l}\text { Attitude towards } \\
\text { antibiotic resistance }\end{array}$ & $\begin{array}{l}\text { Frequency } \\
(\mathbf{N})\end{array}$ & $\begin{array}{l}\text { Percentage } \\
(\%)\end{array}$ \\
\hline Positive attitude & 252 & 96.9 \\
\hline Negative attitude & 8 & 3.1 \\
\hline Total & 260 & 100 \\
\hline
\end{tabular}

Table 6 shows that 137 of $260(52.7 \%)$ of the participants disagreed that they took antibiotics when they had a congested nose and headache. When asked if they at one point asked doctors to prescribe antibiotics when they caught a common cold, 131 of 260 (50.4\%) disagreed.

Table 6: Practices of participants towards antibiotic use and resistance $(n=260)$.

\begin{tabular}{|c|c|c|}
\hline Participants practice & $\begin{array}{l}\text { Frequency } \\
\text { (N) }\end{array}$ & $\begin{array}{l}\text { Percentage } \\
(\%)\end{array}$ \\
\hline \multicolumn{3}{|c|}{$\begin{array}{l}\text { Do you take antibiotics when you have a congested } \\
\text { nose and headache? }\end{array}$} \\
\hline Strongly agree & 7 & 2.7 \\
\hline Agree & 47 & 18.1 \\
\hline Neutral & 23 & 8.8 \\
\hline Disagree & 137 & 52.7 \\
\hline Strongly disagree & 46 & 17.7 \\
\hline \multicolumn{3}{|c|}{$\begin{array}{l}\text { Have you asked doctors to prescribe antibiotics for } \\
\text { your common cold? }\end{array}$} \\
\hline Strongly agree & 7 & 2.7 \\
\hline Agree & 45 & 17.3 \\
\hline Neutral & 17 & 6.5 \\
\hline Disagree & 131 & 50.4 \\
\hline Strongly disagree & 60 & 23.1 \\
\hline \multicolumn{3}{|c|}{$\begin{array}{l}\text { Better to stop course of antibiotics once symptoms of } \\
\text { illness get resolved }\end{array}$} \\
\hline Strongly agree & 7 & 2.7 \\
\hline Correct response (no) & 212 & 81.5 \\
\hline Wrong response (yes) & 48 & 18.5 \\
\hline
\end{tabular}

Table 7: Practices of participants towards antibiotic resistance.

\begin{tabular}{|lll|}
\hline $\begin{array}{l}\text { Practices on antibiotic } \\
\text { resistance }\end{array}$ & $\begin{array}{l}\text { Frequency } \\
(\mathbf{N})\end{array}$ & $\begin{array}{l}\text { Percentage } \\
(\%)\end{array}$ \\
\hline Good practices & 195 & 75 \\
\hline Poor practices & 65 & 25 \\
\hline Total & 260 & 100 \\
\hline
\end{tabular}

Table 7 shows that 195 or $260(75 \%)$ of the participants had good practices while 65 of 260 (25\%) had poor practices towards antibiotic resistance.

Relationship between the year of study and level of knowledge on antibiotic resistance

The results were significant with a Chi-square of 16.333 and a $\mathrm{p}$ value of 0.003 . This meant that there was a significant difference in knowledge about antibiotic resistance and year of study. The seventh-year medical students were more knowledgeable about antibiotic resistance compared to the other years of study.

\section{Relationship between the year of study and their attitude towards antibiotic resistance}

The results were non-significant with a Chi-square test of 4.061 and a $\mathrm{p}$ value of 0.398 . This meant that there was no significant difference in attitude on antibiotic resistance and the year of study. Third-year medical students had a better attitude towards antibiotic resistance compared to the other years of study.

\section{Relationship between the year of study and the practices towards antibiotic resistance}

The results were significant with a Chi-square of 10.926 and a $\mathrm{p}$ value of 0.027 . This meant that there was a significant difference in practices about antibiotic resistance and year of study. Seventh-year medical students had better practices towards antibiotic resistance compared to the other years of study.

\section{DISCUSSION}

The present study assessed the knowledge, attitude, and practices of medical students about antibiotic resistance. In the current study, $68.1 \%$ were male while $31.9 \%$ were female. This is different from a study done in Malaysia, there was more female participation representing $72 \%$ while $28 \%$ were male. ${ }^{23}$ In Nepal, the majority of the participants in the study were female representing $63.7 \%$ while $36.3 \%$ were male. ${ }^{24}$ In China, a female predominance was observed of which females were $63.7 \%$ while $36.3 \%$ were male. ${ }^{25}$ The difference could be attributed to the fact that Malaysia, Nepal, and China enroll more female than male students in their medical Universities.

The current study had the largest participation from the third year $(23.5 \%)$, this was followed by fourth-year students $20.4 \%$, sixth year students $20.0 \%$, the fifth year students had $18.8 \%$ and the least was seventh year class $17.3 \%$. This trend in Zambia indicates that many students are enrolling in medical studies. This differs from a study that was done by Huang and colleagues among Chinese medical students in which the majority of participants were from the fourth year. ${ }^{22}$ The difference could be due to differences in sample size. 
Most of the respondents were Christians $97.7 \%$ because Zambia is a Christian nation, followed by others $1.5 \%$ this encompassed Buddhism, mixed Buddhism and Hinduism and also those who are not religious and the least was Islam 2 of $260(0.8 \%)$. In contrast, a study done in Malaysia found that $84 \%$ were Muslim, Hindu $8 \%$, Buddhist $6 \%$, and Christian 1\%. The difference could be attributed to the fact that Malaysia is a Muslim-majority nation thus you would not find many Christians or Hindus. $^{23}$

\section{Knowledge of participants of antibiotic use and resistance}

In this present study, 99.2\% responded correctly that antibiotics are used to treat bacterial infections. The present study thus reported an overall good knowledge of antibiotic use and resistance which was similar to what Dutt and colleagues reported in India. ${ }^{26}$ In Italy, similarly, the majority of the participants were aware that antibiotics are useful for treating bacterial infections $(95.2 \%){ }^{7}$ Another study in India reported a high level of knowledge on the usefulness of antibiotics in treating bacterial infections. ${ }^{27}$ Khajuria et al in India similarly reported that $90 \%$ of the medical students knew the indication of antibiotics. $^{28}$ The reason for this could be because participants might have come across this topic in medical microbiology, pharmacology, and practicals for clinical students.

A high level of correct response $(93.5 \%)$ in the present study was observed to the statement that antibiotics cannot cure viral infections. This is similar to a study that was done in Saudi Arabia in which the majority of the medical students denied that antibiotics are very useful in the treatment of viral infections. ${ }^{29}$ Some studies also reported that medical students denied that antibiotics are very useful in the treatment of viral infections. ${ }^{27,30,31}$ This disagreement with the use of antibiotics in treating viral infections could be because students have learned about this in courses such as pharmacology.

In the present study, half of the students $(50 \%)$ said that antibiotics speed up recovery from a cold while half of them refused. In India, a study reported that $38 \%$ of the participants agreed that antibiotics are useful in treating viral infections and $60 \%$ of these participants further agreed that antibiotics must be taken for someone to recover from a common cold. ${ }^{4}$

All the students in the present study accepted that they have heard of antibiotic resistance. This is similar to the findings by Gupta et al among medical students in India. ${ }^{27}$ In Nigeria, Ajibola et al found similar findings. ${ }^{32}$

In our study, $93.1 \%$ of the medical students correctly responded that frequent use of antibiotics can lead to antibiotic resistance and reduced effectiveness of treatment. Our findings are similar to a study by Khan et al who reported that $85 \%$ of the medical students correctly responded that the frequent use of antibiotics can lead to antibiotic resistance and hence lead to ineffective treatment and the additional burden of medical cost to the patient. $^{4}$

Overall the results of the study showed that $87.3 \%$ had good knowledge while $12.7 \%$ had poor knowledge regarding antibiotic use and resistance. Final year students had a higher level of knowledge than the other years of study. Other studies have also reported good knowledge on antibiotic use and resistance among medical students. $3,4,7,24,33$

\section{The attitude of participants towards antibiotic use and resistance}

In our study, $86.9 \%$ of the participants agreed that the abuse of antibiotics is one of the factors leading to bacterial resistance. These results are similar to the results obtained in China in which $83.88 \%$ of the medical students considered the abuse of antibiotics as one of the main causes of bacterial resistance. ${ }^{22}$ Abuse of antibiotics has been reported by many other researchers as one of the main factors leading to antibiotic resistance. , $^{4,28,34}$

Regarding the necessity to get more education about antibiotics and antibiotic resistance, $95.8 \%$ of the participants in our study agreed that it was necessary. Further, $76.9 \%$ of the participants in our study agreed that education on the rational use of antibiotics is very cardinal. This is consistent with a study that was done in South Africa in which most of the medical students reported that they would appreciate more education on the appropriate use of antibiotics. ${ }^{35}$ Other studies have reported that adequate education on the rational use of antibiotics and antibiotic resistance is very important for medical students as they are the future prescribers. ${ }^{36,37}$

In the present study, $82.3 \%$ of the participants agreed that it is necessary to carry out large scale antibiotics campaign promotion. This is similar to a study done by Huang and colleagues in which $81.96 \%$ of the medical students thought it was necessary to launch certain large scale publicity to promote understanding of antibiotics. ${ }^{22}$ The similarity could be linked to the fact that there are no large scale campaigns that could alert people on antibiotic use and antibiotic resistance.

Overall the results of the study showed that $96.9 \%$ of the participants had a positive attitude while $3.1 \%$ had a negative attitude towards antibiotic use and resistance. The third-year medical students had a better attitude towards antibiotic resistance compared to the other years of study. In Nepal, a higher level of attitude towards antibiotic use and resistance was reported among final year medical students than first-year medical students. ${ }^{24}$ 


\section{Practices of participants with regards to antibiotic use and resistance}

Our study reported that $70.4 \%$ of the participants disagreed with the statement that they take antibiotics when experiencing a headache. In China, a study reported that the majority of the participants disagreed that they take antibiotics when they have a headache. ${ }^{25}$ This shows that very few medical students wrongly use antibiotics to treat headaches.

Regarding the participants' practice on whether they asked doctors to prescribe antibiotics when they caught a common cold, $73.5 \%$ disagreed, $17.3 \%$ agreed, $6.5 \%$ neutral, and $2.7 \%$ strongly agreed. The majority of the students disagreed but there was a minority who believed that antibiotics are used to treat a common cold. This is similar to a study done in western China where more than $10 \%$ of students incorrectly believed that antibiotics should be used for common colds. ${ }^{38}$ In China, it was reported that $13.6 \%$ of the medical students used antibiotics for a common cold. ${ }^{22}$ Similarly, other studies have also reported that usage of antibiotics among medical students for treatment of a common cold. ${ }^{3,7,39}$

In the present study, the majority of the medical students $(81.5 \%)$ disagreed that it is better to stop a course of antibiotics immediately when symptoms of illness get resolved. The findings of our study are similar to the findings of Bharath et al who reported that the majority of the medical students $(75 \%)$ were aware that it is important to complete a course of antibiotics. ${ }^{40}$ Scaioli et al reported that $94.8 \%$ while Kanneppady et al reported that $87.6 \%$ of the medical students were aware that it is mandatory to complete the full course of antibiotics even if the symptoms resolved. ${ }^{7,37}$

Overall the results of the study showed that $75 \%$ of the participants had good practices while $25 \%$ had poor practices towards antibiotic use and resistance. Seventh year medical had better practices towards antibiotic resistance compared to the other years of study. In Nepal, a very low practice was reported with first-year students having a higher level of practice than final year students. ${ }^{24}$ Antibiotic resistance can be reduced by improving the knowledge, attitude, and practices of healthcare providers on antibiotic use and resistance.

\section{CONCLUSION}

This study showed that medical students had good knowledge concerning antibiotic resistance. The study also showed that medical students had a good attitude and practices towards antibiotics antibiotic resistance. The study reported a high score in attitude than knowledge and practices. Lastly, improvements in antibiotic usage and prescribing must be made in the medical curriculum for undergraduate students to reduce the emergence of antibiotic-resistant bacteria.

\section{ACKNOWLEDGEMENTS}

We would like to acknowledge the students in the School of Medicine at the University of Zambia for their participation in the study. We also pay special gratitude to the University of Zambia for allowing us to conduct this study.

\section{Funding: No funding sources \\ Conflict of interest: None declared}

Ethical approval: The study was approved by the University of Zambia Health Sciences Research Ethics Committee (UNZAHSREC), protocol ID: 20190217049, IORG no: 0009227.

\section{REFERENCES}

1. World Health Organisation (WHO). Antimicrobial Resistance Global Report on Surveillance. 2014. Geneva: World Health Organisation. Available at: http://www.who.int/drugresistance/documents/surveil lancereport/en/. Accessed on 5 September 2019.

2. Thriemer K, Katuala Y, Batoko B, Alworonga J-P, Devlieger $\mathrm{H}$, Van Geet C, et al. Antibiotic Prescribing in DR Congo: A Knowledge, Attitude and Practice Survey among Medical Doctors and Students. PLoS ONE. 2013;8(2):e55495.

3. Sharma S, Jayakumar D, Palappallil DS, Kesavan KP. Knowledge, attitude and practices of antibiotic usage and resistance among the second year MBBS Students. Int J Basic Clin Pharmacol. 2016;5(3):899903.

4. Khan AK, Banu G, Reshma K. Antibiotic resistance and usage - A survey on the knowledge, attitude, perceptions, and practices among the medical students of a Southern Indian teaching hospital. J Clin Diagn Res. 2013;7:1613-6.

5. Byarugaba DK. A view on antimicrobial resistance in developing countries and responsible risk factors. Int J Antimicrob Agents 2004;24:105-10.

6. Vlieghe E, Phoba M, Tamfun J, Jacobs J. Antibiotic resistance among bacterial pathogens in Central Africa: a review of the published literature between 1955 and 2008. Int J Antimicrob. Ag 2009;34:295303.

7. Scaioli G, Gualano MR, Gili R, Masucci S, Bert F, Siliquini R. Antibiotic use: A cross-sectional survey assessing the knowledge, attitudes, and Practices amongst Students of a School of Medicine in Italy. PLoS One. 2015;10:e0122476.

8. Jamshed SQ, Elkalmi R, Rajiah K, Al-Shami AK, Shamsudin SH, Siddiqui MJ, et al. Understanding of antibiotic use and resistance among final-year pharmacy and medical students: A pilot study. J Infect Dev Ctries. 2014;8:780-5.

9. Om C, Daily F, Vlieghe E, McLaughlin JC, McLaws ML. If it's a broad spectrum, it can shoot better": Inappropriate antibiotic prescribing in Cambodia. Antimicrob Resist Infect Control. 2016;5:58. 
10. Ganesh M, Sridevi S, Paul C. Antibiotic use among medical and Paramedical students: knowledge, attitude and it's practice in a tertiary health care Centre in Chennai - a scientific insight. Int J Sci Res. 2014;3:332-5.

11. Desai AJ, Gayathri GV, Mehta DS. Public's Perception, Knowledge, Attitude, and Behaviour on Antibiotic Resistance - A survey in Davangere City, India. J Prevent Med Holistic Health. 2016;2(1):1723.

12. Masaiti GC, Malambo C, Hikaambo $\mathrm{C}$, et al. Antibacterial Properties of Ficus sycomorus Bark Extract Against Staphylococcus aureus and Escherichia coli. Int J Biomed Investig. 2019;2:121.

13. Fischbach MA, Walsh CT. Antibiotics for emerging pathogens. Science. 2009;325:1089-93.

14. Tenover FC. Mechanisms of antimicrobial resistance in bacteria. Am J Med. 2006;119:3-10.

15. Blair JM, Webber MA, Baylay AJ, Ogbolu DO \& Piddock LJ. Molecular mechanisms of antibiotic resistance. Nat. Rev. Microbiol. 2015;13:42-51.

16. Sefton AM. Mechanism sofanti microbial resistance. Drugs 2002;62:557-66.

17. Mudenda S, Bangara FF, Sitali J, Banda M. Knowledge, Attitude, and Practices on Antibiotic Resistance among Pharmacists at the University Teaching Hospitals in Lusaka, Zambia. J Harmonized Res. 2019;8(2):12-24.

18. Tegagn GT, Yadesa TM and Ahmed Y, Knowledge, Attitudes and Practices of Healthcare Professionals towards Antimicrobial Stewardship and Their Predictors in Fitche Hospital. J Bioanal Biomed. 2017;9:91-7.

19. Ohl CA, Dodds Ashley ES. Antimicrobial stewardship programs in community hospitals: The evidence base and case studies. Clin Infect Dis. 2011;53:23-8.

20. Paterson DL. The role of antimicrobial management programs in optimizing antibiotic prescribing within hospitals. Clin Infect Dis. 2006;42(2):90-5.

21. Chuenchom N, Thamlikitkul V, Chaiwarith R, Deoisares R, Rattanaumpawan P. Perception, attitude, and knowledge regarding antimicrobial resistance, appropriate antimicrobial use, and infection control among future medical practitioners: A multicenter study. Infect Control Hosp Epidemiol. 2016;37:603-5.

22. Huang Y, Gu J, Zhang M, Ren Z, Yang W, Chen Y, et al. Knowledge, attitude and practice of antibiotics: A questionnaire study among 2500 Chinese students. BMC Med Educ. 2013;13:163.

23. Haque M, Rahman NIA, Zulkifli Z, Ismail S. Antibiotic prescribing and resistance: knowledge level of medical students of clinical years of University Sultan Zainal Abidin, Malaysia. J Therap Clin Risk Management. 2016;12:413.

24. Shah P, Shrestha R, Mao Z, Chen Y, Chen Y, Koju P, et al. Knowledge, Attitude, and Practice Associated with Antibiotic Use among University Students: A
Survey in Nepal. Int J Environ Res Public Health. 2019; 16:3996.

25. Hu Y, Wang X, Tucker DJ, Little P, Moore M, Fukuda K, et al. Knowledge, Attitude, and Practice with Respect to Antibiotic Use among Chinese Medical Students: A Multicenter Cross-Sectional Study. Int $\mathbf{J}$ Environ Res Public Health. 2018; $15: 1165$.

26. Dutt HK, Sarkhil MZ, Hasseb MA, Singh G. A comparative knowledge, attitude, and practice study of antimicrobial use, self-medication and antimicrobial resistance among final year students of MBBS, BDS, and BSc Nursing at a tertiary care hospital at Kannur. Natl J Physiol Pharm Pharmacol. 2018;8(9):1305-11.

27. Gupta MK, Vohra C, Raghav P. Assessment of knowledge, attitudes, and practices about antibiotic resistance among medical students in India. J Family Med Prim Care. 2019;8:2864-9.

28. Khajuria K, Kaur S, Sadiq S, Khajuria V. KAP on antibiotic usage and resistance among second professional medical students. Int $\mathrm{J}$ Basic Clin Pharmacol. 2019;8:68-73.

29. Harakeh S, Almatrafi M,Ungapen H, Hammad R, Olayan F, Hakim R, et al. Perceptions of medical students towards antibiotic prescribing for upper respiratory tract infections in Saudi Arabia. BMJ Open Respir Res. 2015;2:e00078.

30. Nair M, Tripathi S, Mazumdar S, Mahajan R, Harshana A, Pereira A, et al. Knowledge, attitudes, and practices related to antibiotic use in Paschim Bardhaman district: A survey of healthcare providers in West Bengal, India. PLoS One. 2019; 14:e0217818.

31. Ahmad A, Khan MU, Patel I, Maharaj S, Pandey S, Dhingra S. Knowledge, attitude and practice of B. Sc. Pharmacy students about antibiotics in Trinidad and Tobago. J Res Pharm Pract. 2015;4:37-41.

32. Ajibola O, Omisakin O, Eze A, Omoleke S. Selfmedication with antibiotics, attitude, and knowledge of antibiotic resistance among community residents and undergraduate students in Northwest Nigeria. Diseases. 2018;6:32.

33. Suaifan GA, Shehadeh M, Darwish DA, Al-Ije H, Yousef AM, Darwish RM. A cross-sectional study on knowledge, attitude, and behavior related to antibiotic use and resistance among medical and nonmedical university students in Jordan. Afr $\mathbf{J}$ Pharmacy Pharmacol. 2012;15:6(10):763-70.

34. Dyar OJ, Pulcini C, Howard P, Nathwani D, ESGAP (ESCMID Study Group for Antibiotic Policies). European medical students: A first multicentre study of knowledge, attitudes, and perceptions of antibiotic prescribing and antibiotic resistance. J Antimicrob Chemother. 2014;69:842-6.

35. Wasserman S, Potgieter S, Shoul E, Constant D, Stewart A, Mendelson M, et al. South African medical students' perceptions and knowledge about antibiotic resistance and appropriate prescribing: Are 
we providing adequate training to future prescribers? S Afr Med J. 2017;107:405-10.

36. Davenport LA, Davey PG, Ker JS. BSAC Undergraduate Education Working Party. An outcome-based approach for teaching prudent antimicrobial prescribing to undergraduate medical students: Report of a working party of the British Society for Antimicrobial Chemotherapy. J Antimicrob Chemother. 2005;56:196-203.

37. Kanneppady SS, Oo AM, Lwin OM, Ahmed AlAbed AAA, Kanneppady SK. Knowledge, attitude, and awareness of antibiotic resistance among medical students. Arch Med Health Sci. 2019;7:57-60.

38. Lv B, Zhou Z, Xu G, Yang D, Wu L, Shen Q, et al. Knowledge, attitudes and practices concerning selfmedication with antibiotics among university students in western China. Trop Med Int Health. 2014;19(7):769-79.
39. Badiger S, Kundapur R, Jain A, Kumar A, Pattanshetty S, Thakolkaran N, et al. Self-medication patterns among medical students in South India. Australas Med J. 2012;5:217-20.

40. Bharath Kumar VD, Monika N, Kalpana L, Veena RM, Sathish Chandra MR. Assessment of awareness about antibiotic resistance among first-year medical undergraduates in a medical college. Int $\mathbf{J}$ Clin Pharmacol Res. 2015;5:239-42.

Cite this article as: Zulu A, Matafwali SK, Banda M, Mudenda S. Assessment of knowledge, attitude and practices on antibiotic resistance among undergraduate medical students in the school of medicine at the University of Zambia. Int J Basic Clin Pharmacol 2020;9:263-70. 